\title{
Comparison between Ayrshire, Friesian and Finnish cattle dairy cows on home - produced feeds
}

\author{
ELSI ETTALA
}

\author{
The Agricultural Research Centre \\ North Savo Experimental Station, SF-71750 Maaninka, Finland
}

\begin{abstract}
An experiment with Ayrshire (Ay), Friesian (Fr) and Finnish cattle ( $F c)$ animals on homeproduced feeds under same kind of conditions is conducted at North Savo Experimental Station in the years $1979-87$. The test animals $(40 \mathrm{Ay}, 40 \mathrm{Fr}, 16 \mathrm{Fc}$ ) was taken by random sampling when they were calves. One half of the animals of each race receives silage-grain feeding, the other half hay-grain-urea feeding.

The growth rate of the calves was equal in the beginning but later on the Friesian animals grew fastest and the Finnish cattle animals most slowly. The average milk yield of the first lactation year was at the same level in the Friesian groups and in the Ayrshire hay-group. The first milk yield of the Ayrshire silage-group was a little lower than of those mentioned before and clearly lower in the Finnish cattle groups. The milk yields were a consequence of the feed consumptions of the animals. In the second lactation year the feed consumptions and the milk yields have increased distinctly. There are not to be found differences in the conception rates depending on races.
\end{abstract}

\section{Aim of the research}

The aim of this long-term experiment ( 8 years) is to find out characteristic features of the dairy cattle races in Finland under same kind of conditions fed by home-produced feeds. The most important objects to be cleared up are: - milk yield of the cows

- consumption of roughages at the different stages of lactation

- feed conversion

- fertility

- diseases

- economic result

\section{Experimental procedures}

The test animals. The animals were taken for this study by random sampling so that heifers were inseminated by young bulls in 1978 in different parts of 
Finland. 96 cows (40 Ayrshire, 40 Friesian and 16 Finnish cattle) had 84 different fathers. Because some of the bulls had two daughters they were put into different feeding groups. Also spare calves were taken in the study, altogether 50 Ayrshire, 50 Friesian and 20 Finnish cattle calves started the experiment.

The calves were brought to the experimental station from 25 th of May to 18 th of July, 1979. The average ages and live weights of the calves when arriving were:

\begin{tabular}{lccc}
\hline & Ayrshire & Friesian & Finnish cattle \\
\hline Age, days & 51 & 53 & 50 \\
Live weight, $\mathrm{kg}$ & 54 & 57 & 48 \\
\hline
\end{tabular}

The test calves were rather heterogenic in size and to their condition.

Other procedures. The animals are to be fed all their lives individually. All feeds and residues are weighed daily. Samples of different feeds are taken continuously. The milk yield is weighed individually at each milking time. The composition of the milk is analysed once a week. A veterinarian is presently conducting a fertility study and the information about diseases will be filed up. The growing animals are weighed twice a month and the cows once a month, on two successive days.

\section{Feeding}

The races are devided into two feeding groups. Both groups are fed with domestic feeds. One group eats ad libitum unwilted, flail-harvested grass silage preserved with AIV 2-solution (formic acid $83 \%$ plus orthophosphoric acid $2 \%$ ), and grain, and one kilo of hay since prelactational feeding of heifers. The other group eats hay ad libitum, and grain added with 2 percent of urea as protein supplement as well as extra vitamins. Both groups receive vitamins in the mineral mixtures. The grain consists of $2 / 3$ barley and $1 / 3$ oats.

By the amount of grain for the growing animals the average live weight gain is tried to get to be $600-700 \mathrm{~g}$ per day. The hay group eats grain 1,5 kilos per day, the grain ration of the silage group is reduced $(1,5-1,0-0,6-0,0 \mathrm{~kg})$ when the consumption of silage increases.

The amount of the grain ration of the cows depends on the milk yield as follows:

\begin{tabular}{ccc}
\hline $\begin{array}{c}\text { Milk yield } \\
\text { (4 percent fat) } \\
\mathrm{kg} \text { /day per cow }\end{array}$ & $\begin{array}{c}\text { Grain f.u./kg of milk (4 percent fat) } \\
\text { Silage } \\
\text { group }\end{array}$ & $\begin{array}{c}\text { Hay } \\
\text { group }\end{array}$ \\
\hline-15 & 0,24 & 0.32 \\
20 & 0,26 & 0,34 \\
25 & 0,28 & 0,36 \\
$30-$ & 0,30 & 0,38 \\
\hline
\end{tabular}


The grain ration is programmed into a computer and it changes stepless according to the milk yield, also taking into account the amount of milk the previous days.

Before the experimental diet there was a transition period of two weeks after the calves were 3,5 months of age, now in 1983 after the age of 3 months. Before that the calves received skimmilk powder, grain and hay or silage.

\section{Growth results}

The feeding on the experimental station made quite rapidly the growth of the animals arriving from different conditions fairly equal. The mean growth rate of different races in the first weeks was the same:

\begin{tabular}{lcccc}
\hline Live weight & \multicolumn{5}{c}{ Weeks } \\
\hline & 1 st & 2 nd & 3 rd & 4 th \\
\hline Ayrshire, kg & 54 & 58 & 63 & 67 \\
Friesian, kg & 57 & 61 & 66 & 70 \\
Finnish cattle, kg & 48 & 52 & 57 & 61 \\
\hline
\end{tabular}

When the test feeding started the ages and the live weights of the groups were as follows:

\begin{tabular}{lccc}
\hline & No. of calves & Age, days & Live weight, kg \\
\hline $\begin{array}{l}\text { Ayrshire group } \\
\text { Silage }\end{array}$ & 25 & 121 & \\
$\quad$ Hay-urea & 25 & 121 & 96,9 \\
$\begin{array}{l}\text { Friesian group } \\
\text { Silage }\end{array}$ & 25 & 111 & 95,7 \\
$\quad$ Hay-urea & 25 & 111 & 93,5 \\
$\begin{array}{l}\text { Finnish cattle group } \\
\text { Silage }\end{array}$ & 10 & & 93,2 \\
$\quad$ Hay-urea & 10 & 115 & 88,0 \\
\hline & & 116 & 90,0 \\
\hline
\end{tabular}

A clear difference in the live weight gain between different races began at the age of about 9 months (Fig. 1, Table 1). The animals in the silage group grew faster than the animals in the hay group (Table 2). The Friesian heifers ate particularly much silage. The growth in this group was also clearly greater than in the other groups. The consumption of hay of the Finnish cattle cows was clearly lower than that of the other groups and also the growth rate of this group was poorer than the growth of the others.

\section{Heat and conception rates of heifers}

The Ayrshire and Friesian heifers had their first heat on an average at the same weight (abt. $260 \mathrm{~kg}$ ). The difference in the age between these races was 


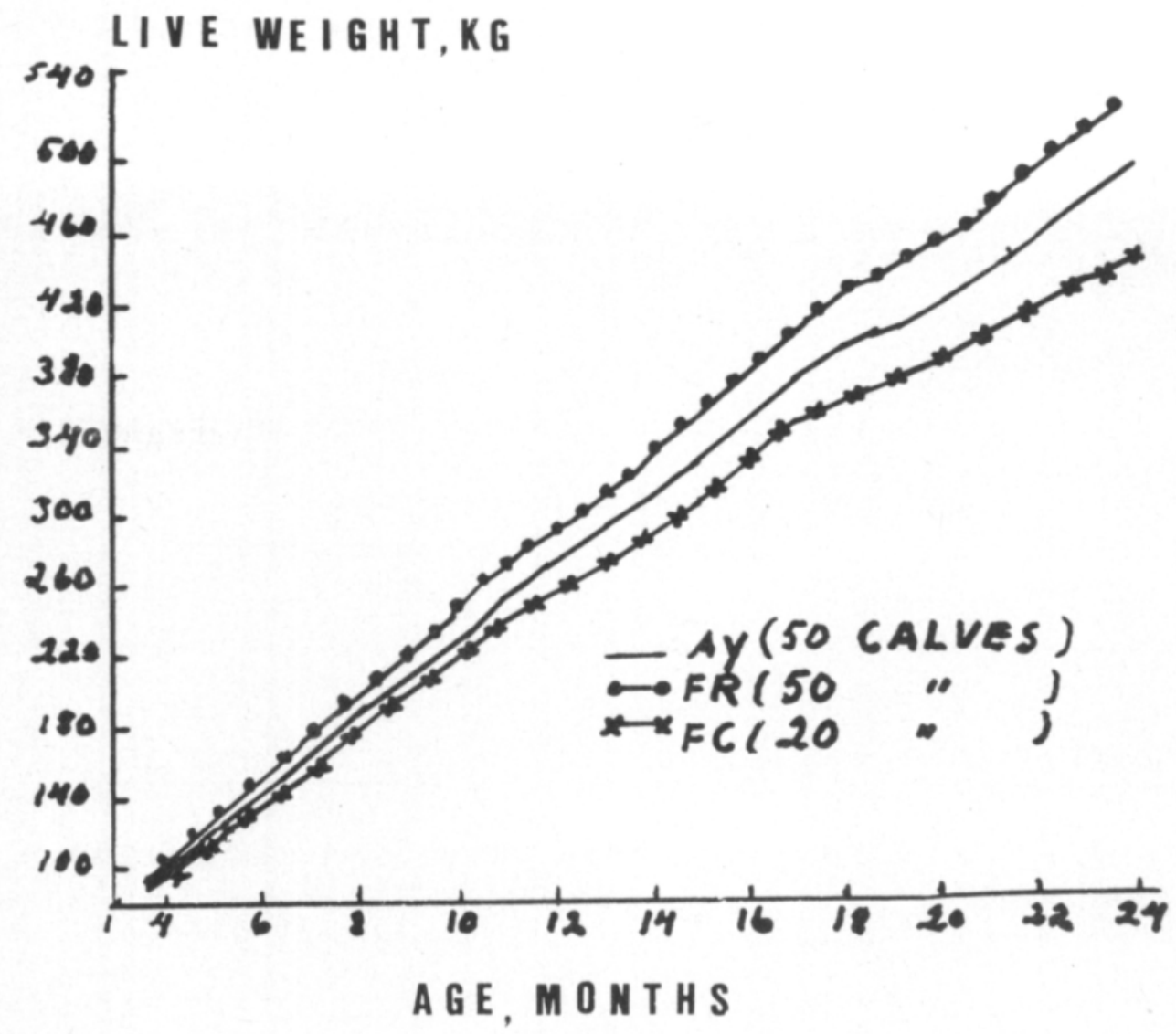

Fig. 1. Live weight gain of calves of different races on the North Savo Experimental Station.

Table 1. Average liveweights and growth rates of different races at different ages.

\begin{tabular}{llcll}
\multicolumn{5}{c}{ Age, months ${ }^{1)}$} \\
\hline 6 & 9 & 12 & 15 & 18
\end{tabular}

\section{Live weight. $\mathrm{kg}$}

$\begin{array}{llllll}\text { Ay } & 151 & 212 & 282 & 332 & 390 \\ \text { Fr } & 149 & 217 & 293 & 350 & 414 \\ \text { Fc } & 140 & 199 & 261 & 307 & 358\end{array}$

Growth rate, $g$ per day

$\begin{array}{llllll}\text { Ay } & 783 & 748 & 734 & 699 & 698 \\ \text { Fr } & 797 & 800 & 793 & 763 & 763 \\ \text { Fc } & 723 & 716 & 683 & 648 & 641\end{array}$

1) Age in months is an approximate value, the animals are weighed at two weeks intervals and there is a difference of five to ten days between the races.

Observations:
Ay $=$ Ayrshire
$\mathrm{Fr}=$ Friesian
$\mathrm{Fc}=$ Finnish cattle 
Table 2. Average live weight and growth rates of different races by the age of two years.

\begin{tabular}{lcc}
\hline & Silage group & Hay-urea group \\
\hline Live weight, $k g$ & & \\
Ay & 511 & 483 \\
Fr & 558 & 506 \\
Fc & 466 & 414 \\
Growth rate g per day & & \\
Ay & 686 & 644 \\
Fr & 771 & 685 \\
Fc & 628 & 537 \\
\hline
\end{tabular}

Table 3. Age and live weight of heifers during their first heat.

\begin{tabular}{|c|c|c|c|c|c|c|}
\hline & \multirow{2}{*}{$\begin{array}{l}\text { No. of } \\
\text { heifers }\end{array}$} & \multicolumn{2}{|c|}{ Age, months } & \multicolumn{2}{|c|}{ Live weight, $\mathrm{kg}$} & \multirow[t]{2}{*}{ Daily gain, $g$} \\
\hline & & mean & range & mean & range & \\
\hline \multicolumn{7}{|c|}{ Ayrshire group } \\
\hline Silage & 24 & 10.9 & $9,0-13,6$ & 261 & $215-323$ & 779 \\
\hline Hay-urea & 25 & 11,8 & $10,3-13,3$ & 262 & $221-329$ & 705 \\
\hline \multicolumn{7}{|c|}{ Friesian group } \\
\hline Silage & 25 & 10,1 & $8,3-11,8$ & 264 & $229-346$ & 877 \\
\hline Hay-urea & 25 & 11,1 & $9,8-13,0$ & 259 & $204-300$ & 736 \\
\hline \multicolumn{7}{|c|}{ Finnish cattle group } \\
\hline Silage & 10 & 10,0 & $8,3-11,6$ & 233 & 193-282 & 774 \\
\hline Hay-urea & 10 & 10,4 & $8,9-12,3$ & 215 & $180-243$ & 634 \\
\hline
\end{tabular}

thereby under one month (Table 3). When the Finnish cattle heifers had their first heat they were younger and smaller than Ayrshire and Friesian heifers. The heifers in the silage groups had their heat earlier than the slowlier grown heifers in the hay groups.

All races and both feeding groups had silent and strong heats. The length of the heat cycle (average 20,8 days, range from 18 to 26 days) was not found to be dependent on races or feeding. The duration of heat in Ayrshire heifers was a bit shorter (average 2,8 days) than the heat of other races (average 3,4 days). The heifers were inseminated at the mean age of 16 months (Table 4). The bigger ones were inseminated at the first heat after the age of 15 months and the smaller ones at their first heat after the age of 16 months. The limits for live weights were: Ayrshire heifers $320 \mathrm{~kg}$, Friesian heifers $340 \mathrm{~kg}$ and Finnish cattle heifers $300 \mathrm{~kg}$. Most of the heifers weighed considerably more (Table 4).

The conception rate was good. After the first insemination on an average 75,6 percent of the heifers conceived, and 90,8 percent after the second insemination (Table 5). One Friesian heifer did not conceive at all. 
Table 4. Age and live weight of heifers during inseminations followed by gestation.

\begin{tabular}{|c|c|c|c|c|c|c|c|}
\hline \multirow{3}{*}{ Ayrshire grour } & \multicolumn{4}{|c|}{ Age, months } & & \multicolumn{2}{|c|}{ Live weight, $\mathrm{kg}$} \\
\hline & \multirow[t]{2}{*}{ mean } & \multicolumn{4}{|c|}{ range } & \multirow[t]{2}{*}{ mean } & \multirow{2}{*}{ range } \\
\hline & & \multirow{2}{*}{\multicolumn{2}{|c|}{15 months }} & \multirow{2}{*}{\multicolumn{2}{|c|}{13 days - }} & & \\
\hline \multirow[t]{2}{*}{ Silage } & \multirow[t]{2}{*}{15,9} & & & & & \multirow[t]{2}{*}{363} & \multirow[t]{2}{*}{$317-492$} \\
\hline & & & $"$ & 23 & & & \\
\hline \multirow[t]{2}{*}{ Hay-urea } & \multirow[t]{2}{*}{16,1} & 15 & $n$ & 12 & $"$ & & \\
\hline & & 17 & $n$ & 24 & $"$ & 350 & $308-416$ \\
\hline \multicolumn{8}{|c|}{ Friesian group } \\
\hline \multirow[t]{2}{*}{ Silage } & \multirow[t]{2}{*}{16,1} & 15 & $”$ & 6 & $"$ & \multirow[t]{2}{*}{397} & \multirow[t]{2}{*}{$345-450$} \\
\hline & & 17 & $"$ & 22 & $"$ & & \\
\hline \multirow[t]{2}{*}{ Hay-urea } & \multirow[t]{2}{*}{16,0} & 15 & $"$ & 3 & $"$ & \multirow[t]{2}{*}{367} & \multirow[t]{2}{*}{$332-399$} \\
\hline & & 17 & $"$ & 22 & $"$ & & \\
\hline \multicolumn{8}{|c|}{ Finnish cattle group } \\
\hline \multirow[t]{2}{*}{ Silage } & \multirow[t]{2}{*}{15,9} & 15 & $"$ & 0 & $"$ & \multirow[t]{2}{*}{340} & \multirow[t]{2}{*}{ 294-411 } \\
\hline & & 16 & $"$ & 29 & $"$ & & \\
\hline \multirow[t]{2}{*}{ Hay-urea } & \multirow[t]{2}{*}{16,5} & 15 & $"$ & 14 & $"$ & \multirow[t]{2}{*}{327} & \multirow[t]{2}{*}{$287-386$} \\
\hline & & 18 & $"$ & 10 & $n$ & & \\
\hline
\end{tabular}

Table 5. Conception rate of heifers in 1980.

\begin{tabular}{|c|c|c|c|c|c|}
\hline & \multicolumn{5}{|c|}{ Conception rate, $\%$} \\
\hline & $\begin{array}{l}\text { Insemination } \\
\quad 1 .\end{array}$ & 2. & 3. & 4. or more & total \\
\hline \multicolumn{6}{|c|}{ Ayrshire group } \\
\hline Silage & 75,0 & 20,8 & 4,2 & - & 100,0 \\
\hline Hay-urea & 92,0 & 4,0 & - & 4,0 & 100,0 \\
\hline \multicolumn{6}{|l|}{ Friesian group } \\
\hline Silage & 68,0 & 16,0 & 4,0 & 12,0 & 100,0 \\
\hline Hay-urea & 72,0 & 20,0 & 4,0 & - & 96,0 \\
\hline \multicolumn{6}{|c|}{ Finnish cattle group } \\
\hline Silage & 70,0 & 20,0 & 10,0 & - & 100,0 \\
\hline Hay-urea & 70,0 & 10,0 & 20,0 & - & 100,0 \\
\hline Average & 75,6 & 15,1 & 5,0 & 3,4 & 99,2 \\
\hline Ayrshire & 83,7 & 12,2 & 2,0 & 2,0 & 100,0 \\
\hline Friesian & 70,0 & 18,0 & 4,0 & 6,0 & 98,0 \\
\hline Finnish cattle & 70,0 & 15,0 & 15,0 & - & 100,0 \\
\hline
\end{tabular}

\section{Calving}

The heifers calved at the age of a little over 25 months (Table 6). There were no differences depending on the races in the length of the gestation (range from 8 months 21 days to 9 months 13 days).

The Friesian heifers of the silage group had difficult calvings and dead calves distinctly more than the others had (Tables 7 and 8). The reason was evidently the obesity caused by abundant consumption of silage; the difficulties of Friesian heifers on hay feeding were minor. The size of the calves of all races had remarkable variation (Table 9). Differences between races or feeding groups in retention of afterbirth (Table 8) were not be seen. 
Table 6. Calving age and average live weight of heifers before and after the calving in 1981.

\begin{tabular}{|c|c|c|c|c|c|c|c|c|c|c|c|c|}
\hline & \multirow{2}{*}{$\begin{array}{l}\text { No. of } \\
\text { animals }\end{array}$} & \multicolumn{6}{|c|}{ Age, months } & & & & \multicolumn{2}{|c|}{ Live weight, kg } \\
\hline & & & mean & & & & ange & & & & $\begin{array}{l}\text { before } \\
\text { calving }\end{array}$ & $\begin{array}{l}\text { after } \\
\text { calving }\end{array}$ \\
\hline \multicolumn{13}{|c|}{ Ayrshire group } \\
\hline Silage & 20 & 25 & nonths & & days & $\begin{array}{l}24 r \\
26\end{array}$ & onth & $\begin{array}{l}12 \\
17\end{array}$ & days - & & 523 & 462 \\
\hline Hay-urea & 20 & 25 & $"$ & 10 & $"$ & $\begin{array}{l}24 \\
27\end{array}$ & $\begin{array}{l}n \\
n\end{array}$ & $\begin{array}{r}16 \\
5\end{array}$ & " & - & 509 & 449 \\
\hline \multicolumn{13}{|c|}{ Friesian group } \\
\hline Silage & 20 & 25 & $"$ & 10 & $"$ & $\begin{array}{l}24 \\
27\end{array}$ & $n$ & $\begin{array}{r}2 \\
25\end{array}$ & $n$ & - & 583 & 512 \\
\hline Hay-urea & 20 & 25 & $"$ & 5 & $"$ & $\begin{array}{l}24 \\
26\end{array}$ & $"$ & $\begin{array}{r}6 \\
23\end{array}$ & $"$ & - & 528 & 462 \\
\hline \multicolumn{13}{|c|}{ Finnish cattle group } \\
\hline Silage & 8 & 25 & $n$ & 5 & $"$ & $\begin{array}{l}24 \\
26\end{array}$ & $n$ & $\begin{array}{l}8 \\
5\end{array}$ & $"$ & - & 469 & 416 \\
\hline Hay-urea & 8 & 25 & $"$ & 26 & $"$ & $\begin{array}{l}24 \\
27\end{array}$ & $n$ & $\begin{array}{l}23 \\
18\end{array}$ & $"$ & - & 446 & 406 \\
\hline
\end{tabular}

Table 7. Difficulties during the first and the second calving in 1981 and 1982.

\begin{tabular}{|c|c|c|c|c|c|c|c|c|}
\hline & \multirow{3}{*}{$\begin{array}{c}\text { No. of } \\
\text { animals }\end{array}$} & \multicolumn{3}{|c|}{ First calving 1981} & \multirow{3}{*}{$\begin{array}{c}\text { No. of } \\
\text { animals }\end{array}$} & \multirow{2}{*}{\multicolumn{3}{|c|}{$\begin{array}{c}\text { Second calving } 1982 \\
\% \text { of calvings }\end{array}$}} \\
\hline & & \multicolumn{3}{|c|}{$\%$ of calvings } & & & & \\
\hline & & easy & normal & difficult & & easy & normal & difficult \\
\hline Ay & 48 & 33,3 & 60,4 & 6,3 & 39 & 33,3 & 64,1 & 2.6 \\
\hline Fr & 48 & 35,5 & 39,6 & 25,0 & 40 & 22,5 & 70,0 & 7,5 \\
\hline \multirow[t]{2}{*}{$\mathrm{Fc}$} & 20 & 55,0 & 45,0 & - & 16 & 25,0 & 62,5 & 12,5 \\
\hline & Total & & & & Total & & & \\
\hline Average & 116 & 37,9 & 49,1 & 12,9 & 95 & 27,4 & 66,3 & 6,4 \\
\hline Silage groups & 57 & 31,6 & 47,4 & 21,1 & 47 & 25,5 & 70,2 & 4,3 \\
\hline Hay-urea groups & 59 & 44,1 & 50,8 & 5,1 & 48 & 29,2 & 62,5 & 8,3 \\
\hline
\end{tabular}

Easy $=$ easy, guick and painless, goes without helping

Normal $=$ normal, during two hours, without helping or with one - two persons help

Difficult $=$ difficult, takes time, many helpers.

Table 8. Dead calves and retention of afterbirth during the first and the second calving in 1981 and 1982.

\begin{tabular}{|c|c|c|c|c|c|c|c|c|c|c|}
\hline & \multirow{3}{*}{$\begin{array}{c}\text { No. of } \\
\text { animals }\end{array}$} & \multicolumn{4}{|c|}{ First calving 1981} & \multirow{3}{*}{$\begin{array}{c}\text { No. of } \\
\text { animals }\end{array}$} & \multicolumn{4}{|c|}{ Second calving 1982} \\
\hline & & \multicolumn{2}{|c|}{$\begin{array}{l}\text { Dead } \\
\text { calves }\end{array}$} & \multicolumn{2}{|c|}{$\begin{array}{l}\text { Retention of } \\
\text { afterbirth }\end{array}$} & & \multicolumn{2}{|c|}{$\begin{array}{l}\text { Dead } \\
\text { calves }\end{array}$} & \multicolumn{2}{|c|}{$\begin{array}{l}\text { Retention of } \\
\text { afterbirth }\end{array}$} \\
\hline & & no. & $\%$ & no. & $\%$ & & no. & $\%$ & no. & $\%$ \\
\hline Ay & 48 & 2 & 4,2 & 4 & 8,3 & 39 & - & - & 4 & 10,3 \\
\hline $\mathrm{Fr}$ & 48 & 9 & 18,8 & 3 & 6,3 & 40 & - & - & 3 & 7,5 \\
\hline \multirow[t]{2}{*}{$\mathrm{Fc}$} & 20 & 1 & 5,0 & 1 & 5,0 & 16 & - & - & 2 & 12,5 \\
\hline & Total & & & & & Total & & & & \\
\hline Average & 116 & 12 & 10,3 & 8 & 6,9 & 95 & - & - & 9 & 9,5 \\
\hline Silage groups & 57 & 9 & 15,8 & 3 & 5,3 & 47 & - & - & 3 & 6,4 \\
\hline Hay-urea groups & 59 & 3 & 5,1 & 5 & 8,5 & 48 & - & - & 6 & 12,5 \\
\hline
\end{tabular}


Table 9. Birth weight of calves of the first and the second calving in 1981 and 1982.

\begin{tabular}{|c|c|c|c|c|}
\hline & \multicolumn{4}{|c|}{ Birth weight, $\mathrm{kg}$} \\
\hline & \multicolumn{2}{|c|}{ First calving } & \multicolumn{2}{|c|}{ Second calving } \\
\hline & mean & range & mean & range \\
\hline \multicolumn{5}{|c|}{ Ayrshire group } \\
\hline Silage & 37,5 & $32-47$ & 36,0 & $27-45$ \\
\hline Hay-urea & 37,8 & $26-47$ & 33,3 & $21-44$ \\
\hline \multicolumn{5}{|c|}{ Friesian group } \\
\hline Silage & 38,5 & $31-46$ & 41,4 & $35-49$ \\
\hline Hay-urea & 39,6 & $25-43$ & 38,3 & $30-49$ \\
\hline \multicolumn{5}{|l|}{ Finnish cattle } \\
\hline Silage & 26,5 & $20-32$ & 32,5 & 23-37 \\
\hline Hay-urea & 27,2 & $23-35$ & 29,4 & $25-34$ \\
\hline Average & 36,4 & $20-47$ & 36,2 & $21-49$ \\
\hline Ay & 37,7 & $26-47$ & 34,6 & $21-45$ \\
\hline Fr & 39,1 & $25-46$ & 39,9 & $30-49$ \\
\hline $\mathrm{Fc}$ & 26,9 & $20-35$ & 31,0 & 23-37 \\
\hline Silage & 36,0 & $20-47$ & 37,7 & $23-49$ \\
\hline Hay-urea & 36,7 & $23-47$ & 34,7 & $21-49$ \\
\hline
\end{tabular}

\section{Milk yield}

\section{The first lactation year}

The milk yields of Ayrshire and Friesian cows in the peak of their first lactation were practically the same in the hay-grain-urea groups (Table 10). The milk production also continued to be the same during the whole lactation period (Fig. 2). On the other hand, Ayrshire cows in their first lactation on silage-grain feeding produced less than the Friesian cows. The peak of the first lactation of all races was higher in hay-grain-urea feeding

Table 10. Peaks of the first lactation in 1981.

\begin{tabular}{lccc}
\hline & $\begin{array}{c}\text { No. of } \\
\text { animals }\end{array}$ & \multicolumn{2}{c}{ Milk yield, kg/day per cow } \\
\cline { 4 - 4 } & & & range \\
\hline $\begin{array}{l}\text { Ayrshire group } \\
\quad \text { Silage }\end{array}$ & 20 & 18,5 & $15,0-23,6$ \\
$\quad$ Hay-urea & 20 & 21,6 & $17,7-27.5$ \\
Friesian group & & & \\
$\quad$ Silage & 20 & 19,9 & $12,8-26,2$ \\
$\quad$ Hay-urea & 20 & 21,7 & $17,4-26,7$ \\
Finnish cattle group & & & \\
$\quad$ Silage & 8 & 15,2 & $11,0-23,8$ \\
$\quad$ Hay-urea & 8 & 17,1 & $11,4-21,9$ \\
\hline
\end{tabular}




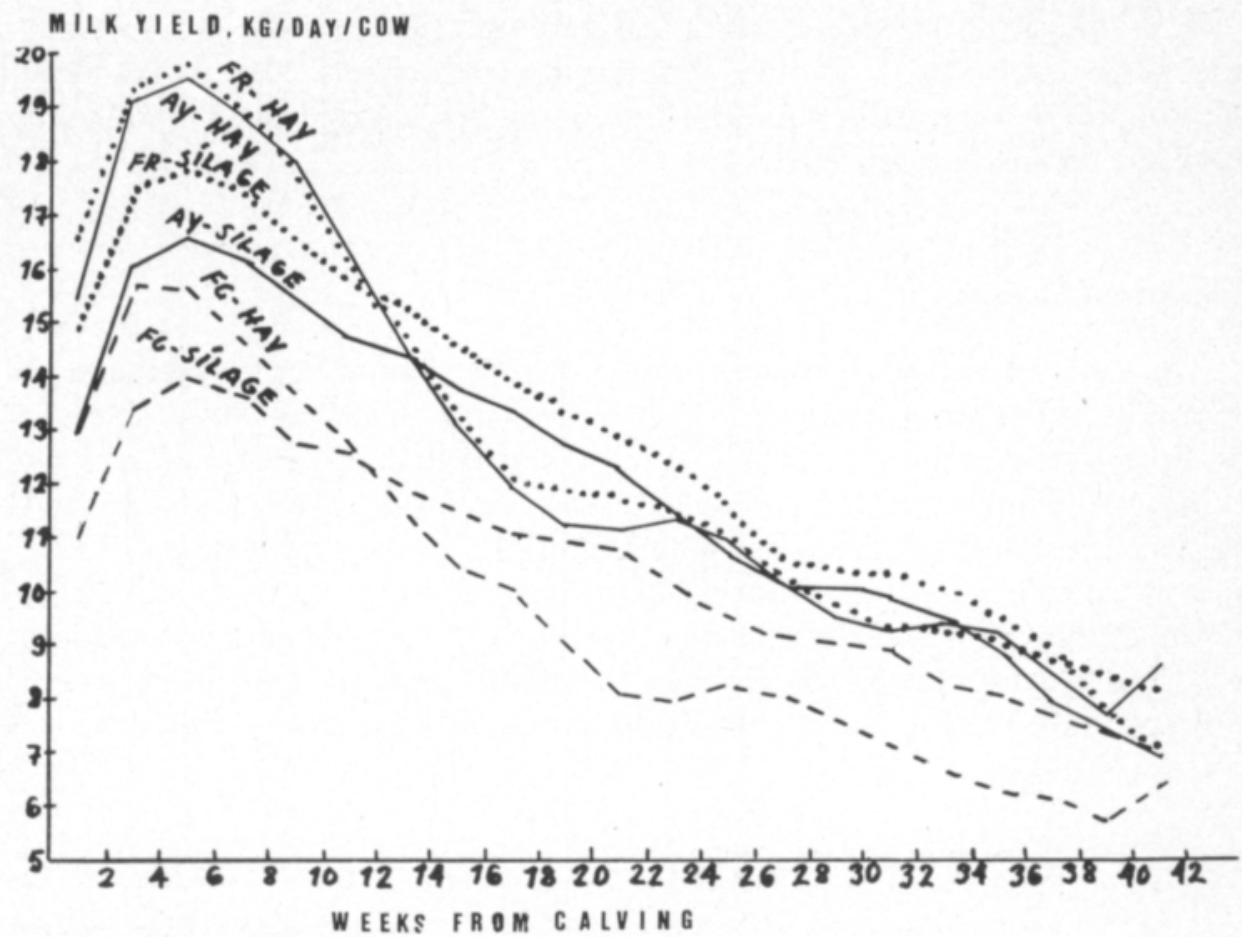

Fig. 2. Milk yield of the first lactation year in 1981.

than in silage-grain but the production decreased faster. The grain ration had evidently an effect on the shape of the lactation curve.

The average milk yields of 4 percent fat-corrected milk (FCM) in the first lactation were quantitatively very much the same in both the Friesian groups and in the hay group of Ayrshire (Table 11). The milk yield of the Ayrshire cows in the silage group was slightly lower than of those mentioned above. The milk yields of the Finnish cattle were lower than others. They produced more with silage than with hay feeding.

Table 11. Fat corrected (4 per cent) milk yield of the first lactation year.

\begin{tabular}{lccc}
\hline & $\begin{array}{c}\text { No. of } \\
\text { animals }\end{array}$ & $\begin{array}{c}\text { Milk yield, 4 per cent } \\
\text { FCM kg/year per cow }\end{array}$ \\
\cline { 3 - 4 } $\begin{array}{l}\text { Ayrshire group } \\
\text { Silage }\end{array}$ & 20 & 3888 & range \\
$\quad$ Hay-urea & 20 & 4065 & $3285-4802$ \\
$\begin{array}{l}\text { Friesian group } \\
\text { Silage }\end{array}$ & & $3412-4840$ \\
$\quad$ Hay-urea & 20 & 3993 & $2888-5363$ \\
Finnish cattle group & 20 & $3344-5002$ \\
$\quad \begin{array}{l}\text { Silage } \\
\text { Hay-urea }\end{array}$ & 8 & 3387 & $2284-4742$ \\
\hline
\end{tabular}


The attention is drawn to the great variation (Tables 10 and 11) in the milk yields of the first lactation. Among the test animals taken by random sampling there were really poor and good individuals but most of them were, however, on the average level.

\section{The second lactation year}

The sescond lactation year of some of the cows is not yet finished and so the results of the whole year are not so far available. The peaks of lactation in the second production year were distinctly higher than those of the first year (Table 12). The best ones produced $30 \mathrm{~kg}$ or more. Both Ayrshire and Friesian cows, both on silage and with hay feeding, altogether 16,8 percent of the cows, produced $30 \mathrm{~kg}$ or more. A part of the cows have already calved for the third time. The peaks of the milk production have still increased (Table 13). The results look very good when taking into account that the feeds are home-produced and the test animals were taken by random sampling.

Table 12. Peaks of the second lactation in 1982.

\begin{tabular}{lccc}
\hline & $\begin{array}{c}\text { No. of } \\
\text { animals }\end{array}$ & \multicolumn{2}{c}{ Milk yield, kg/day per cow } \\
\cline { 3 - 4 } & & & range \\
\hline $\begin{array}{l}\text { Ayrshire group } \\
\text { Silage }\end{array}$ & 19 & 25,2 & $19,2-30,6$ \\
$\quad$ Hay-urea & 20 & 25,6 & $22,4^{1)}-32,3$ \\
$\begin{array}{l}\text { Friesian group } \\
\quad \text { Silage }\end{array}$ & 20 & 26,3 & $20,3-33,1$ \\
$\quad$ Hay-urea & 20 & 27,1 & $22,9^{1)}-32,4$ \\
Finnish cattle group & & & $16,7-26,8$ \\
$\quad \begin{array}{l}\text { Silage } \\
\text { Hay-urea }\end{array}$ & 8 & 18,3 & $15,6-24,1$ \\
\hline
\end{tabular}

1) Two cows calved before the set time (at 7-8 months) and produced only 11,3 and $13,6 \mathrm{~kg} / \mathrm{day}$.

Table 13. Peaks of the third lactation in 1983.

\begin{tabular}{lccc}
\hline & $\begin{array}{c}\text { No. of } \\
\text { animals }\end{array}$ & \multicolumn{2}{c}{ Milk yield, kg/day per cow } \\
\cline { 4 - 4 } & & & range \\
\hline $\begin{array}{l}\text { Ayrshire group } \\
\quad \text { Silage }\end{array}$ & 18 & 26,5 & $21,0-31,0$ \\
$\quad$ Hay-urea & 20 & 27,8 & $20,0-34,4$ \\
$\quad \begin{array}{l}\text { Friesian group } \\
\text { Silage }\end{array}$ & 17 & & \\
$\quad$ Hay-urea & 17 & 30,2 & $17,7-35,2$ \\
Finnish cattle group & & & $20,3-38,0$ \\
$\quad$ Silage & 8 & 24,4 & $18,7-29,7$ \\
$\quad$ Hay-urea & 7 & 24,1 & $17,6-29,2$ \\
\hline
\end{tabular}




\section{Composition of the milk}

The fat content of the milk of all the races was surprisingly high (Table 14). The milk protein content on the contrary was below the average value $(3,30$ percent $)$ in the milk of the first lactation. In the beginning of the second lactation year the protein content of the milk, however, began to raise. The Friesian cows had both the fat and the protein contents slightly lower than others.

\section{Feed consumption}

The feed consumption in the first lactation year explains the differences in the milk yield. The Ayrshire and the Friesian cows ate hay equally much during the first lactation year, but the Ayrshire cows ate distinctly less silage at that time (Table 15). The cows of the Finnish cattle ate in the first lactation year silage relatively more than hay.

Table 14. Composition of the milk in the first lactation in 1981.

\begin{tabular}{|c|c|c|c|c|c|}
\hline & \multirow{2}{*}{$\begin{array}{l}\text { No. of } \\
\text { animals }\end{array}$} & \multicolumn{2}{|c|}{ Fat } & \multicolumn{2}{|c|}{ Protein } \\
\hline & & mean \% & $\mathrm{kg}$ & mean $\%$ & kg \\
\hline \multicolumn{6}{|c|}{ Ayrshire group } \\
\hline Silage & 20 & 4,83 & $138-199$ & 3,18 & $91-146$ \\
\hline Hay-urea & 20 & 4,85 & $147-204$ & 3,20 & $91-140$ \\
\hline \multicolumn{6}{|c|}{ Friesian group } \\
\hline Silage & 20 & 4,60 & 123-232 & 3,08 & $86-146$ \\
\hline Hay-urea & 20 & 4,44 & 133-211 & 3,09 & $95-140$ \\
\hline \multicolumn{6}{|c|}{ Finnish cattle group } \\
\hline Silage & 8 & 4,72 & 93-196 & 3,15 & $69-130$ \\
\hline Hay-urea & 8 & 4,89 & 93-187 & 3,30 & $63-113$ \\
\hline
\end{tabular}

Table 15. Average feed consumption during 10 month's time in the first lactation in 1981-82.

\begin{tabular}{lccccc}
\hline & $\begin{array}{c}\text { No. of } \\
\text { animals }\end{array}$ & $\begin{array}{c}\text { Silage } \\
\mathrm{kg}\end{array}$ & $\begin{array}{c}\text { Hay } \\
\mathrm{kg}\end{array}$ & $\begin{array}{c}\text { Grain } \\
\mathrm{kg}\end{array}$ & $\begin{array}{c}\text { Total } \\
\mathrm{DM}\end{array}$ \\
\hline $\begin{array}{l}\text { Ayrshire group } \\
\quad \text { Silage }\end{array}$ & 20 & 27,8 & 0,9 & 3,3 & 9,5 \\
$\quad$ Hay-urea & 20 & - & 9,1 & 4,7 & 12,1 \\
$\begin{array}{l}\text { Friesian group } \\
\quad \text { Silage }\end{array}$ & 20 & 32,2 & 0,9 & 3,6 & 10,6 \\
$\quad$ Hay-urea & 20 & - & 9,1 & 4,6 & 12,1 \\
$\quad \begin{array}{l}\text { Finnish cattle group } \\
\quad \text { Silage }\end{array}$ & & & & & \\
$\quad$ Hay-urea & 8 & 25,2 & 0,7 & 3,0 & 8,5 \\
\hline
\end{tabular}

1) Grain is supplemented with minerals and with 2 per cent urea and 0,5 per cent DEB-Karjavitan (vitamins) on hay feeding. 
The consumption increased remarkably during the second lactation year (Table 16). So far we have, however, the results of the feed consumption of the first seven months of the second lactation year only. The trend is quite the same as it was during the first year. The Ayrshire and the Friesian cows have been eating hay the same quantity but the Ayrshire cows have been eating silage less than the Friesian cows. The difference in the consumption of silage between the Ayrshire and the Friesian cows is bigger than between the Ayrshire and the Finnish cattle cows. The Finnish cattle cows have increased the consumption of hay during the second year more than the cows of the bigger races.

\section{Nutrient supply}

When the study was planned the aim was to have quantitatively the same amount of nutrient in both the silage and the hay groups. Therefore the hay group received more grain supplemented with urea as an extra protein source.

The nutrient balance of Friesian and Finnish cattle groups in the first year was surprisingly good (Table 17). The hay group of Ayrshire cows was an exception, which after eating hay as much as the Friesian cows obtained also feed units equally much as the Friesian cows and passed the silage group of the Ayrshire cows. Therefore the milk yield of Ayrshire cows during the first lactation year was less on silage than on hay.

The same trend in supply of nutrients continued during the second lactation year (Table 18). All other races but not the Ayrshire had the same average consumption of feed units and digestible crude protein in different feeds.

Especially at the peak of the lactation the Ayrshire cows of the silage group did not obtain as much feed units and digestible crude protein as the cows in the hay group (Figs. 3 and 4).

Table 16. Average feed consumption during the first 7 month's time in the second lactation in 1982.

\begin{tabular}{lccccc}
\hline & $\begin{array}{c}\text { No. of } \\
\text { animals }\end{array}$ & $\begin{array}{c}\text { Silage } \\
\mathrm{kg}\end{array}$ & $\begin{array}{c}\mathrm{Hay} \\
\mathrm{kg}\end{array}$ & $\begin{array}{c}\text { Grain } \\
\mathrm{kg}\end{array}$ & $\begin{array}{c}\text { Total } \\
\mathrm{DM}\end{array}$ \\
\hline $\begin{array}{l}\text { Ayrshire group } \\
\quad \text { Silage }\end{array}$ & 19 & 37,0 & 0,9 & 5,4 & 13,2 \\
$\quad$ Hay-urea & 20 & - & 10,4 & 7,1 & 15,4 \\
$\quad \begin{array}{l}\text { Friesian group } \\
\quad \text { Silage }\end{array}$ & 20 & 41,3 & 0,9 & 5,6 & 14,4 \\
$\quad$ Hay-urea & 20 & - & 10,5 & 7,0 & 15,6 \\
$\quad \begin{array}{l}\text { Finnish cattle group } \\
\quad \text { Silage }\end{array}$ & & & & & \\
$\quad$ Hay-urea & 8 & 32,6 & 0,8 & 4,5 & 11,6 \\
\hline
\end{tabular}

1) Same observation as in Table 15. 
Table 17. Average daily nutrient supply during 10 month's time in the first lactation of 1981-82.

\begin{tabular}{|c|c|c|c|c|c|c|c|c|}
\hline & \multicolumn{2}{|c|}{ Silage } & \multicolumn{2}{|c|}{ Hay } & \multicolumn{2}{|c|}{ Grain } & \multicolumn{2}{|c|}{ Total } \\
\hline & f.u & $\mathrm{DCP}, \mathrm{g}$ & f.u. & $\mathrm{DCP}, \mathrm{g}$ & f.u. & $\overline{\mathrm{DCP}, \mathrm{g}}$ & f.u. & $\overline{D C P}, \mathrm{~g}$ \\
\hline \multicolumn{9}{|c|}{ Ayrshire group } \\
\hline Silage & 3,9 & 692 & 0,4 & 52 & 3,1 & 270 & 7,4 & 1014 \\
\hline Hay-urea & - & - & 4,1 & 541 & 4,3 & 525 & 8,4 & 1066 \\
\hline \multicolumn{9}{|c|}{ Friesian group } \\
\hline Silage & 4,5 & 795 & 0,4 & 52 & 3,3 & 292 & 8,3 & 1138 \\
\hline Hay-urea & - & - & 4,1 & 542 & 4,3 & 516 & 8,3 & 1058 \\
\hline \multicolumn{9}{|c|}{ Finnish cattle group } \\
\hline Silage & 3,6 & 625 & 0,3 & 43 & 2,8 & 244 & 6,7 & 911 \\
\hline Hay-urea & - & - & 3,2 & 429 & 3,5 & 425 & 6,7 & 854 \\
\hline
\end{tabular}

f.u. $\quad=$ feed units

$\mathrm{DCP}=$ digestible crude protein

Table 18. Average daily nutrient supply during the first seven month's time in the second lactation year in 1982.

\begin{tabular}{|c|c|c|c|c|c|c|c|c|}
\hline \multirow{2}{*}{ Ayrshire grou } & \multicolumn{2}{|c|}{$\frac{\text { Silage }}{\text { f.u. DCP,g }}$} & \multicolumn{2}{|c|}{$\begin{array}{l}\text { Hay } \\
\text { f.u. DCP,g }\end{array}$} & \multicolumn{2}{|c|}{$\frac{\text { Grain }}{\text { f.u. DCP,g }}$} & \multicolumn{2}{|c|}{$\frac{\text { Total }}{\text { f.u. DCP,g }}$} \\
\hline & & & & & & & & \\
\hline Silage & 5,8 & 970 & 0,5 & 60 & 5,0 & 423 & 11,2 & 1452 \\
\hline Hay-urea & - & - & 5,6 & 694 & 6,5 & 800 & 12,1 & 1494 \\
\hline \multicolumn{9}{|c|}{ Friesian group } \\
\hline Silage & 6,5 & 1077 & 0,5 & 62 & 5,1 & 435 & 12,1 & 1574 \\
\hline Hay-urea & - & - & 5,7 & 704 & 6,5 & 796 & 12,2 & 1500 \\
\hline \multicolumn{9}{|c|}{ Finnish cattle group } \\
\hline Silage & 5,2 & 848 & 0,4 & 55 & 4,2 & 354 & 9,8 & 1257 \\
\hline Hay-urea & - & - & 4,8 & 597 & 5,0 & 619 & 9,8 & 1216 \\
\hline
\end{tabular}

\section{Fertility}

Possible differences in fertility will come out when the years pass. Until now the differences have been considerably great between the years and variable between the races (Table 19). The reasons for this will be glarified later on by computer from an extensive material.

The most important reason of the first lactation year 1981 has been cleared up. When after the first insemination already 69,8 per cent of the cows were conceived there began to appear abortions at an early stage of gestation. The reason was Zearalenoni (S 2), toxin of Fusarium mold in hay of the very rainy summer. Now after the third calving the conception rates look good, but so the summer 1983 was also excellent. 


\section{F.U. I DAY I G. OW}

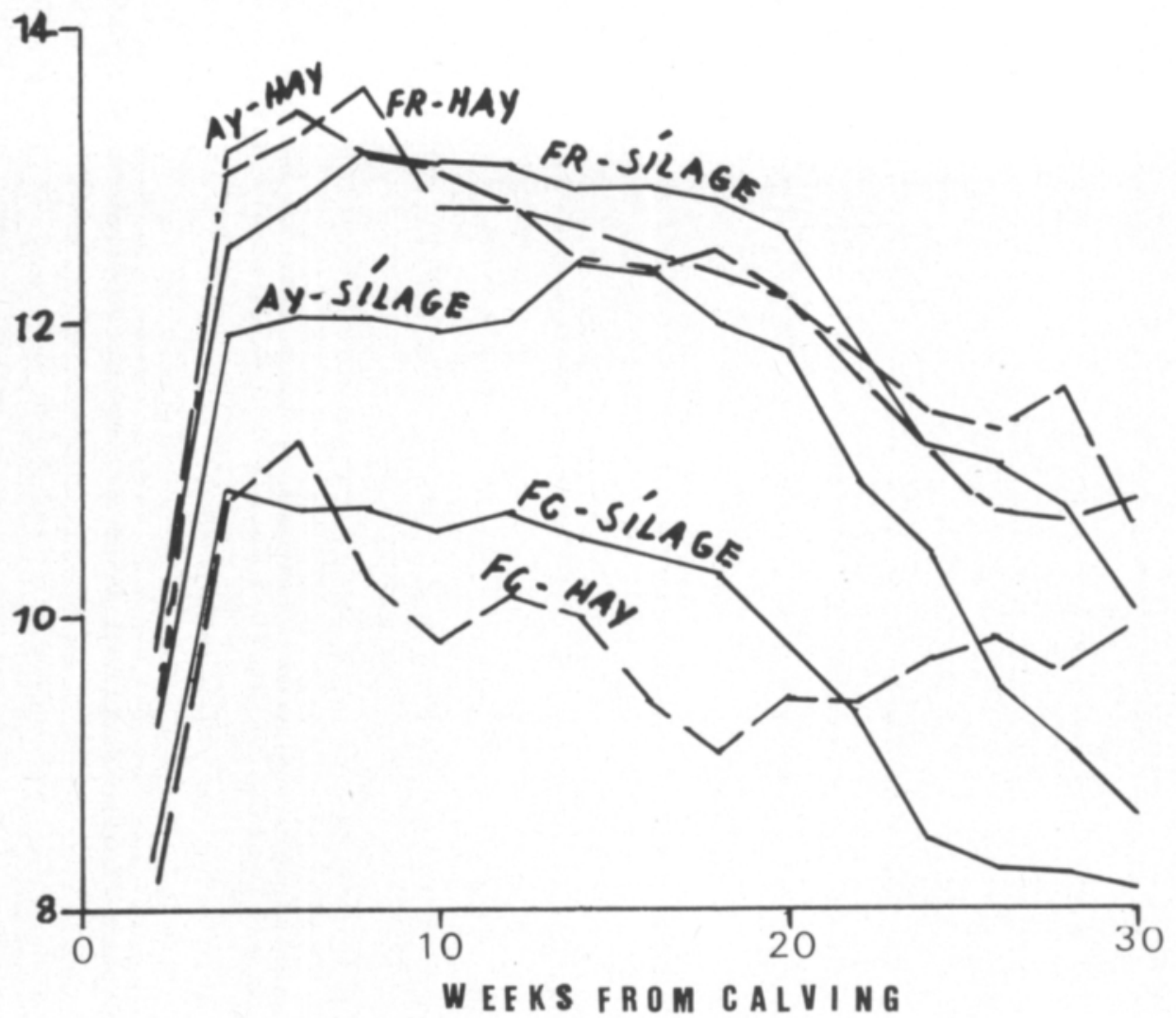

Fig. 3. Daily intake of feed units in 1982.

Table 19. Conception rates in 1980-82.

\begin{tabular}{|c|c|c|c|c|}
\hline & \multirow[b]{2}{*}{$\begin{array}{l}\text { No. of } \\
\text { animals }\end{array}$} & \multicolumn{2}{|c|}{ Conception rate $\%$} & \multirow[b]{2}{*}{$\begin{array}{c}\text { Times of } \\
\text { inseminations } \\
\text { per cow per } \\
\text { gestation }\end{array}$} \\
\hline & & $\begin{array}{l}\text { after the } \\
\text { first } \\
\text { incemi- } \\
\text { nation }\end{array}$ & $\begin{array}{l}\text { after the } \\
\text { first and } \\
\text { second } \\
\text { insemination }\end{array}$ & \\
\hline \multicolumn{5}{|c|}{ Heifers } \\
\hline Ay & 49 & 83,7 & 95,9 & 1,22 \\
\hline Fr & 49 & 70,0 & 88,0 & 1,47 \\
\hline $\mathrm{Fc}$ & 20 & 70,0 & 85,0 & 1,45 \\
\hline \multicolumn{5}{|c|}{ First lactation } \\
\hline Ay & 39 & 62,5 & 72,5 & 1,90 \\
\hline $\mathrm{Fr}$ & 40 & 60,0 & 80,0 & 1,78 \\
\hline $\mathrm{Fc}$ & 16 & 37,5 & 62,5 & 2,44 \\
\hline \multicolumn{5}{|c|}{ After first lactation } \\
\hline Ay & 38 & 47,4 & 84,2 & 2,00 \\
\hline $\mathrm{Fr}$ & 39 & 48,7 & 74,3 & 1,85 \\
\hline $\mathrm{Fc}$ & 16 & 56,3 & 75,1 & 1,81 \\
\hline
\end{tabular}




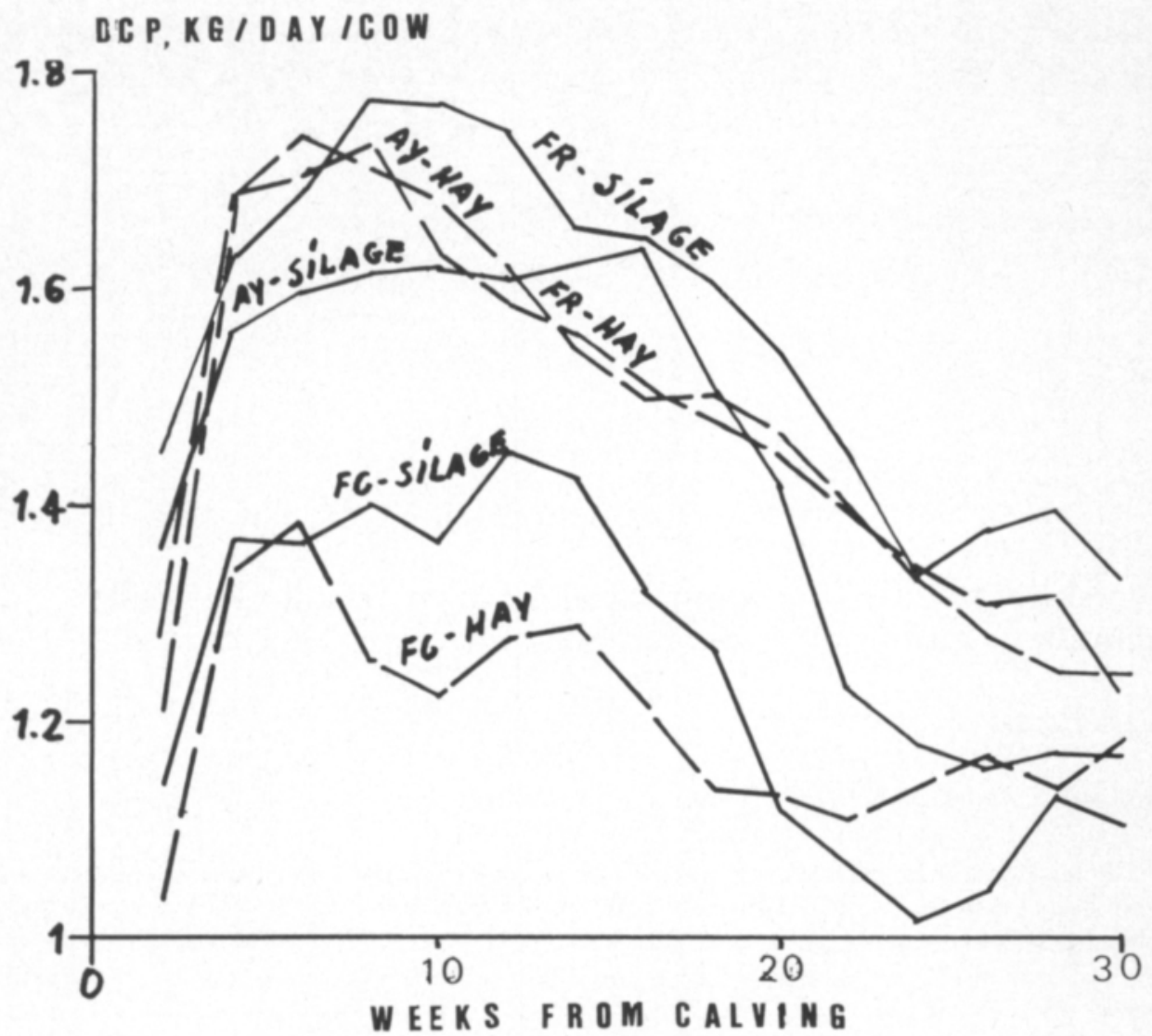

Fig. 4. Daily intake of digestible crude protein in 1982.

Diseases and removals of animals

Mastitis has been the most difficult of the diseases but only three removals have occurred because of it (Table 20). The greatest reason for removals has been leg weakness. Here the Friesian cows have been weaker than the others. Of the cows altogether 16,7 percent have been removed during the two and half years. The endurance of the cows will come out very

Table 20. Removals of cows during two and half years in 1981-83.

\begin{tabular}{lcccc}
\hline Reasons & Ay & Fr & Fc & Total \\
\hline Leg weakness & 1 & 4 & - & 5 \\
Mastitis & - & 2 & 1 & 3 \\
Prolapsus of vagina & 1 & 2 & - & 3 \\
Infertility & 1 & - & - & 1 \\
Other reasons & 2 & 2 & - & 4 \\
\cline { 2 - 5 } & 5 & 10 & 1 & 16 \\
\hline
\end{tabular}


clearly, because the experiment is going to be continued until the end of the year 1987. Then also the final economic result can be figured out.

Ms received December 13, 1983.

\section{Ayrshire-, friisiläis- ja suomenkarjalehmien vertailu kotoisilla rehuilla}

\section{Elsi Ettala}

\section{Pohjois-Savon koeasema, SF 71750 Maaninka}

Pohjois-Savon koeasemalla on meneillään pitkäaikainen ( 8 v) lypsykarjakoe. Kokeessa vertaillaan ayrshire - (ay), friisiläis - (fr) ja suomenkarja - (sk) rotuja samanlaisissa olosuhteissa. Eläinaines otettiin otannalla ja tuotiin koeasemalle v. 1979 vasikoiden ollessa keskimäärin 52 vrk:n ikäisiä. Kokeessa on 40 ay-, 40 fr- ja 16 sk-lehmää. Aluksi oli varaeläimiä, jolloin lukumäärä oli 50 ay-, 50 fr- ja 20 sk-vasikkaa. Koelehmät (96) olivat peräisin 84 :stä eri isästä.

Vertailu tapahtuu kotoisilla rehuilla. Jokainen rotu on jaettu kahtia. Toinen puoli saa säilörehu-viljaruokinnan sekä lehmänä kilon heinää, toinen puoli heinä-vilja-urearuokinnan. Ureaa viljaseoksessa on $2 \%$. Viljaa on heinäryhmällä enemmän $(0,32-0,38 \mathrm{ry} / \mathrm{kg} 4 \%$-maitoa ) kuin säilörehuryhmällä $(0,24-0,30 \mathrm{ry} / \mathrm{kg} 4 \%$-maitoa). Seoksessa on $2 / 3$ ohraa ja $1 / 3$ kauraa. Säilörehua tai heinää eläimet saavat ruokahalun mukaan, jolloin voidaan tutkia niiden karkearehun syöntikyky.

Alussa erirotuisten vasikoiden kasvunopeus oli samaa tasoa, mutta myöhemmin fr-rotuiset kasvoivat nopeimmin ja sk-rotuiset hitaimmin. Hiehot tiinehtyivät hyvin (1. siemennyksestä $75,6 \%$ ) ja poikivat keskimäärin n. 25 kk:n iässä. Poikimisvaikeuksia oli fr-säilörehuryhmän eläimillä. Ne olivat muita lihavampia runsaan säilörehunsyönnin ansiosta.

1. vuoden maitotuotos oli molempien ruokintaryhmien fr-ensikoilla ja ay-heinäryhmän ensikoilla samaa tasoa (ryhmien keskiarvo 3948-4065 kg $4 \%$-maitoa/tuotantokausi). Aysäilörehuryhmän ensikoiden tuotos (3888 kg) oli jonkinverran ja sk-ensikoiden (3182-3387 kg) selvästi edellisiä pienempi. Hajonta saman rodun sisällä oli erittäin suuri. Maidon rasvapitoisuus oli ay- ja sk-lehmillä korkea (ryhmien keskiarvot 4,72-4,89\%) ja fr-ensikoillakin hyvä $(4,44-4,60 \%)$. Maidon valkuaispitoisuus eri ryhmillä vaihteli 3,08 \% :sta 3,30 \% :iin.

Toisen tuotantovuoden tuotosta ei ole vielä tiedossa, mutta herumishuiput olivat hyviä (ryhmien keskiarvot ay:llä ja fr-llä 25,2-27,1 kg maitoa ja sk:lla 18,3-20,3 kg). Kolmantena tuotantovuotena tulokset ovat edelleen nousussa.

Ay-eläimet söivät vähemmän säilörehua, mutta heinää yhtä paljon kuin frïsiläiset. Skeläimet söivät vähiten, mutta suhteellisesti enemmän säilörehua kuin heinää. Toisena tuotantovuotena syöntimäärät olivat huomattavasti suurempia kuin ensikkovuonna. Säilörehu- ja heinäryhmillä oli keskimääräinen ravinnonsaanti varsin yhtäläinen muilla paitsi ay-rodulla, jonka heinäryhmä saavutti ravinnonsaannissa friisiläisten tason.

Ensimmäisen ja toisen poikimisen jälkeen tiinehtyminen ei ollut yhtä hyvä kuin hiehoilla. Selvää rodullista eroa ei ilmennyt. Lehmistä on 2,5 vuoden kuluessa poistettu $16,7 \%$. 